\title{
Which factors support trust in the recommendation process of pension products? Trust and pension products
}

\author{
Philip Maximilian Linhart ${ }^{1} \cdot$ Olaf Stotz $^{1}$ (D)
}

Received: 14 May 2021 / Revised: 30 September 2021 / Accepted: 8 November 2021 / Published online: 30 November 2021

(c) The Author(s) 2021

\begin{abstract}
During the financial crisis of 2008/2009, financial institutions such as banks and insurance companies have lost trust of their customers. In the recommendation process of pension products, trust plays an important role since cash flows from retirement products accrue decades ahead. Using the results from a survey, we find that financial institutions still struggle to deliver trust to their customers when they recommend different categories of retirement products. Other recommending parties such as academic financial experts or close friends, however, are able to establish a high level of trust. We therefore investigate factors of alternative channels to establish trust such as the recommendation process or product features.
\end{abstract}

Keywords Pension products $\cdot$ Trust $\cdot$ Financial literacy

\section{Introduction}

Any decision to save for retirement is a decision with longterm consequences. Consider, for example, a 30-year-old individual who can expect to live until she is over 80 . When she starts saving for retirement, she is anticipating the receipt of cash flows from a retirement product 50 years ahead. Although in theory she should base her retirement decision on the probability distribution of cash flows up to 50 years ahead, appropriate estimates are difficult to derive in practice. Therefore, alternative factors may have a larger impact on retirement decisions. In this paper, we analyze the role of trust (and various dimensions thereof) and how it is related to the decision to buy a specific pension product. Thereby, we follow Rousseau et al. (1998) on how we characterize trust. They define trust as an individual's "willingness to accept vulnerability based upon positive expectations of the intentions or behavior of another" (Rousseau et al. 1998, p. 395). In the context of a financial product, it is important to note that "positive expectations" does not imply an individual's expectation to generate a financial gain with a given product. Rather, it refers to a consumer's confidence that payoffs of the financial product will occur

Olaf Stotz

o.stotz@fs.de

1 Frankfurt School of Finance and Management, Adickesallee 32-34, 60322 Frankfurt am Main, Germany with the promised probability or equivalently, that the price of the product develops as described a priori although the consumer does not need to specify the probability distribution exactly. We follow this general definition of trust since it corresponds well with the long-term nature of a pension product. $^{1}$

On the basis of previous research, we consider trust to be an important factor in financial decisions in general and in the pension domain in particular. In general, trust plays a large role in the economy, since it is associated with stronger GDP growth (Knack and Keefer 1997) and more efficient capital markets (Wei and Zhang 2014). A sharp recession can be associated with a lack of trust in the economy (Sapienza and Zingales 2012). Also, a high level of trust supports stock market participation and portfolio diversification (Georgarakos and Pasini 2011; Guiso et al. 2008). Fungácová et al. (2019) analyze various factors (sociodemographic variables, religious factors, political and economic values) which are potentially related to trust in banks in more than 50 countries. They find that these factors explain only a small fraction (about 5\%) of the cross-individual variation in

\footnotetext{
1 There exist various definitions of trust which use a more granular approach (see, for example, Sheppard and Sherman 1998). Moreover, Moin et al. (2015) states that there are 46 theoretical dimensions of trust although a majority of research studies uses a unidimensional approach. In a survey, however, these multi-dimensions of trust are difficult to distinguish by participants. Therefore, we also use a unidimensional approach which is built on a broad definition of trust of Rousseau et al. (1998).
} 
trust. Thus, trust seems to be characterized by an important individual factor in the general financial context. For recent trends in trust in the financial sector, see also Devlin et al. (2015). In the pension domain, Ricci and Caratelli (2017) and Koh et al. (2021) find that trust tends to positively support retirement planning efforts. Deetlefs et al. (2019) further show that trust has a conditional role in the pension decisions of savers. Less trusting savers tend to display more active decisions, while high trusting savers stick to passive decisions only if they have a low interest in retirement matters. Thereby, empirical evidence suggests that financial literacy seems to have a positive effect on retirement decisions (e.g., Cruijsen et al. 2021). They show that financial literate people in particular display a high level of trust in financial institutions. The recent research in the literature supports the positive role of trust in pension decisions; however, there is less evidence on the role of trust in the process of how retirement products are recommended to savers. Our study aims to fill this gap.

Therefore, we implemented a survey and asked individuals for their perceptions of which factors of a pension product or its recommendation process supports trust. In doing so, we considered four different channels of trust creation. The first channel describes different relationships between the pension investor and the party which recommends a particular pension product. Thereby, we consider a pension product to represent various product categories (specified in the survey, see Appendix) such as a mutual fund or a life insurance but not as a specific product from a particular company. Then, a product category like mutual funds can be recommended by a financial institution-such as a bank-or by a close friend. Different relationships between the investor and the recommending party may then generate different levels of trust (Aggarwal and Larrick 2012; Doney and Cannon 1997; Stewart 2003). This channel is of particular importance for financial institutions, as the financial services sector has been severely struggling to regain consumer confidence in their products and services since the financial crisis of 2008. The second channel refers to product characteristics. One example is that of fairness. If the buyer of a pension product perceives cash flows from a retirement product to be fair, this may foster a high level of trust. The third channel of our analysis includes the recommendation process for a pension product. A product can be recommended, for example, in a face-to-face situation or online. We identify various characteristics of such a recommendation process and investigate their ability to establish a high level of trust. Finally, we look at how regulation of the financial industry is perceived by consumers to create trust. Thereby, we distinguish two different subsectors of the financial industry: the issuers and the sellers of retirement products. In the following section, we describe each of these four channels in detail.
Our results provide various insights on the customer's view of how trust relates to financial products. First and most importantly, typical suppliers of pension productssuch as banks and insurance companies-are perceived to be less trustful institutions, while academic financial experts and friends of the customer are able to generate trust. This observation is confirmed by trust-building attributes like ability, integrity, and customer orientation, all of which can be linked to recommending parties like academic financial experts or family/friends. In addition, product-related features, such as fairness and customization potential, contribute positively to a trustful relationship. If financial products are recommended face to face (as, for example, by friends), people tend to assess this recommendation process as more trustworthy than they do an online recommendation. These results are derived from an online survey of a large sample of young professionals in Germany. We also find that financial literacy seems to be a major factor in building trust. That is, people with a high (low) level of financial literacy tend to display also a high (low) level of trust.

The remainder of this paper is organized as follows: Sect. 2 covers the existing literature on the four channels that determine trust in a wide variety of contexts. Section 3 covers the background of our survey approach, describes our estimation models, and presents a discussion of various variables included in the four channels. Section 4 includes the empirical results of our approach. Section 5 discusses potential explanations as well as implications and drawbacks of our results.

\section{Four dimensions of trust: literature review}

Our literature review summarizes four dimensions of trust: the recommending institution, product-related factors, factors involved in the recommendation process, and regulation of financial products. We discuss each dimension with regard to how trust can be gained. Figure 1 presents an overview of this four-channel structure.

\section{Recommending institutions}

Trust can be transferred from one party to another. For example, Uzzi (1996) shows that individuals can transfer trust from known agents to unknown individuals. Previous work has discussed different channels through which this process occurs. Thereby, this transfer is positively supported if a trusted third party influences the trustor. Even in the World Wide Web, links from trusted Web sites can increase a consumer's trust in unknown organizations, according to Stewart (2003). He shows that there is a purely cognitive process at work in which simply the awareness that a relationship exists between a trusted party and an unknown 
Fig. 1 Trust channels

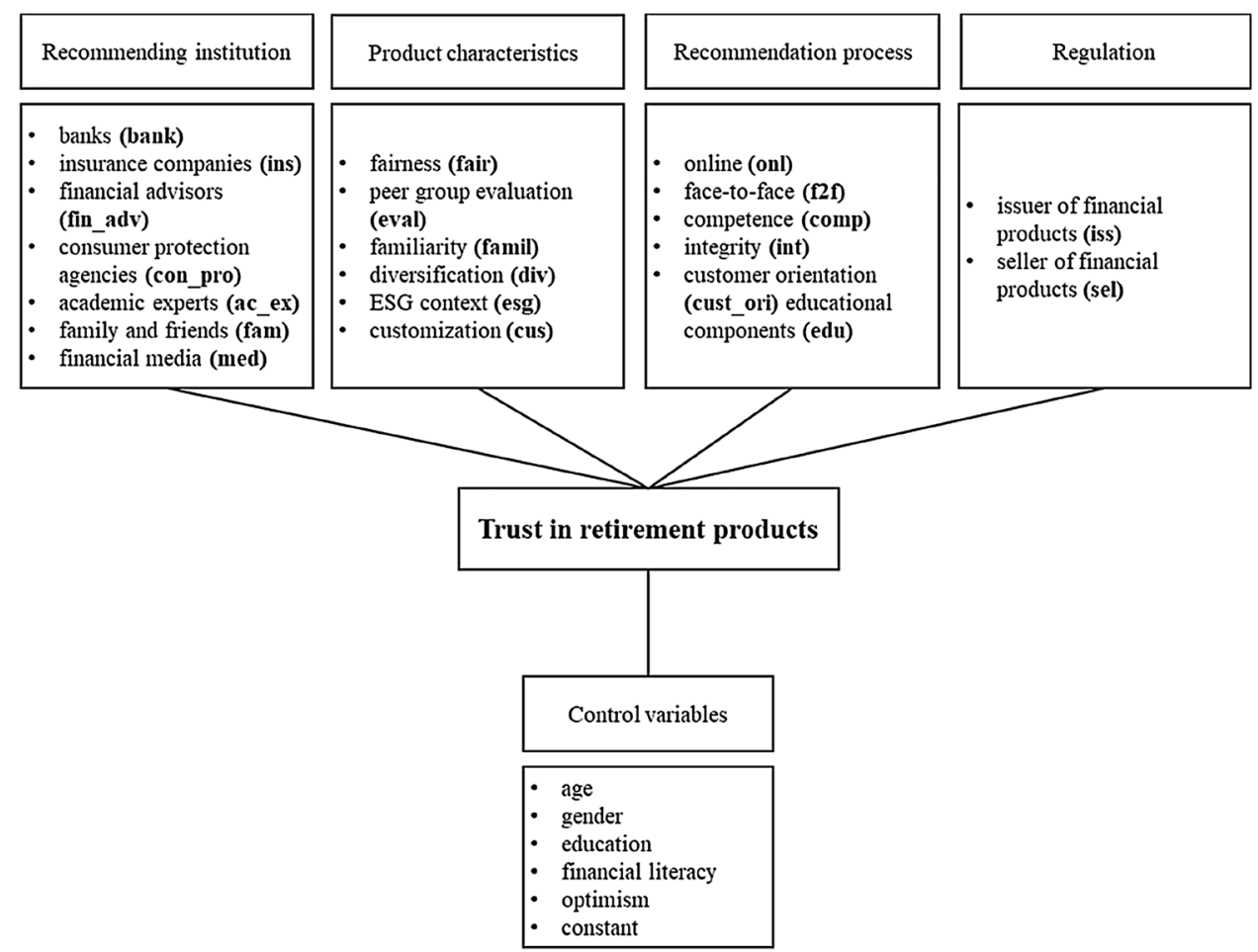

third party suffices to transfer trust. In our study, we therefore include various institutions and analyze how customers perceive an institution's trustworthiness. The most obvious institutions are those closest to the considered pension product, which include banks, insurance companies, and financial advisors. Similarly, there are consumer protection agencies that rate or recommend particular product categories such as exchange traded funds or even specific financial products (e.g., Finanztest by Stiftung Warentest in Germany). Also, a frequently underestimated channel is that of advice given by family and friends (Georgarakos and Pasini 2011; Hong et al. 2004). Finally, the impact of recommendations from academic experts (which primarily recommend product categories instead of specific products) as well as financial media (e.g., magazines, blogs, podcasts, etc.) is also considered.

\section{Product characteristics}

Besides the recommending institution, an alternative determinant of trust is that of the characteristics of the product itself. In this context, the existing literature considers four major channels. The first of these characterizes the perception of distributive fairness (Aggarwal and Larrick 2012). Fairness heuristic theory suggests that individuals use perceived justice as a heuristic to determine whether to trust other individuals (Lind 2001). This concept has also been applied to the banking sector, indicating that fairness positively correlates with trust and trustworthiness (Roy et al. 2015). The practical implication of this finding is analyzed by Loch et al. (2012). They show that the German retail bank TeamBank was able to gain a market share and to increase the bank's profitability by using fairness in its marketing process. This entailed customers paying a higher price (i.e., higher interest rates) when they perceived a financial product to be fair. Second, trust can be increased by providing consensus information from previous customers on a company's product. This channel of increasing trust is similar to Cialdini's (1987) concept of "social proof," whereby consensus information works as a heuristic for decision-making (Chaiken 1989), as consumers use the average opinion as a source of information. This leads to higher levels of trust (Ba and Pavlou 2002). Third, familiarity (Adaval 2003; Benedicktus et al. 2010; Brady et al. 2008; Gulati 1995; Keller 1993; Luhmann 1979; Maheswaran et al. 1992) and customization (Doney and Cannon 1997; Morgan and Hunt 1994; Ostrom and Lacobucci 1995; Williamson 1985) contribute toward building trust by reducing uncertainty about the trustee's behavior. Finally, trust in financial products may be supported by a customer's financial literacy (Coulter and Coulter 2003; Ricci and Caratelli 2017; van der Cruijsen et al. 2021; van Rooij et al. 2007), since financially literate people tend to understand complex financial issues, such as diversification, better than less financially literate people do.

\section{Recommendation process}

Due to the interactive nature of the sales process for financial products, there are several characteristics of the 
recommendation process that one should consider. First, the role of face-to-face interaction in building trust (Benedicktus et al. 2010; Nilsson and Mattes 2013; Storper and Venables 2004) has been well established and might be of significant importance for financial products due to the rise of digital sales channels. Second, the perceived ability of the recommending person/institution has been identified as an important driver of trust in interpersonal relationships (Abrams et al. 2003; Colquitt et al. 2007; Crosby et al.'s 1990; Doney and Cannon 1997; Mayer et al. 1995; Moorman et al. 1993). Third, integrity of the recommending institution (Mayer et al. 1995; McFall 1987; Morgan and Hunt 1994; Sitkin and Roth 1993) appears to be important in this context prima facie. That is, is the financial consultant acting in the best interest of her clients? Finally, an educational component in the recommendation process increases the level of trust in a financial institution (Coulter and Coulter 2003; Ricci and Caratelli 2017; van der Cruijsen et al. 2021; van Rooij et al. 2007). Education is thereby closely related to the financial illiteracy of many customers, and increasing literacy by explaining financial matters helps to increase customer trust in a financial advisor. Finally, benevolence (customer orientation), i.e., acting in the best interest of customers (Larzelere and Huston 1980; Solomon 1960; Strickland 1958), is a well-known driver of trust in general.

\section{Regulation}

The existing academic literature suggests that regulation and institutions have a strong impact on economic decisionmaking (Osili and Paulson 2008) and therefore on trust. As explained by Brodie and Harnack (2019), a certain degree of trust toward products and professions arises from merely being part of a system that is generally trusted. Hence, the characteristics of such systems, including regulation and institutions, have a strong and persistent impact on trust. Osili and Paulson (2008) present evidence from their analysis on stock market participation rates of immigrants in the USA, showing that the character of institutions in immigrants' country of origin continues to influence their decision-making in new environments. Furthermore, in a qualitative analysis of the impact of regulation on trust, Colombo (2010) argues that regulation impacts cognitive and affective trust in a different manner. Regulation helps to foster cognitive trust due to its calculative nature by adding certainty to the equation. Moreover, using various measures of trust (i.e., trust in others, in corporations, or in political institutions) Aghion et al. (2010) show that trust negatively correlates with demand for regulation even in regions where trust in the government is low. Congruently, Pinotti (2012) illustrates that the variation in regulation across countries mainly reflects variation in demand arising from different levels of trust. Thus, the impact of regulation is assessed on two levels, comprising higher regulation for the issuer as well as for the seller of the product.

In sum, the literature suggests that any determinants of trust need to consider its multi-dimensional nature which we do by our broad definition of trust introduced in the introduction. Such determinants can influence trust either directly or by increasing the trustee's trustworthiness (Roy et al. 2015) or increasing an individual's trust propensity (Gill et al. 2005; Mayer et al. 1995), both of which is driven by a collection of character traits and sociodemographic characteristics. Combining those considerations results in the framework visualized in Fig. 1.

\section{Control variables}

Finally, we consider several control variables which are related to a consumer's perception of trust (Fungácová et al. 2019). In the academic literature, this concept is often called "propensity to trust" and it comprises character traits and attitudes of the trustor (Colquitt et al. 2007; Mayer et al. 1995). More precisely, our control vector contains variables adjusting for age (Ennew et al. 2011; Ennew and Sekhon 2007), gender (Buchan et al. 2008; Croson and Gneezy 2009; Dreber and Johannesson 2008; Zeffane and Melhem 2017), and education (Guiso et al. 2004; Alesina and La Ferrara 2002). Furthermore, both the degree of financial literacy (van Rooij et al. 2007) and the individual level of optimism (Puri and Robinson 2007) are included in the control vector, since they have a significant impact on stock market participation and, thus, are likely to determine the level of trust in financial products. We also control for a general level of trust (i.e., trust in other people). Finally, we include an individual specific constant to capture unobserved heterogeneity across individuals.

\section{Conceptual framework}

What determines trust in retirement products? We analyze this question empirically, since an individual's trust is not directly observable. We ask individuals $i$ about their trust in a financial product, denoted by $T$, in various domains $j$, on a Likert scale between 1 (low) and 5 (high). To quantify the relationship between individual factors and the self-reported level of trust in a financial product, we must consider that the dependent variable is an ordered variable. We therefore use ordered logit and probit models of the following structure for our analysis:

$T_{i j}=a_{i}+\beta \cdot X_{j}+\gamma \cdot$ Controls $_{i}+\varepsilon_{i j}$,

where $T$ represents the level of perceived trust in a financial product and $\beta$ is the coefficient for a given dependent 
variable $X_{j}(j=1 \ldots 16$, see Fig. 1$)$. Notice that $X_{j}$ is a dummy variable which equals one if trust in a pension product in domain $j$ is asked for. Controls includes control variables (see Fig. 1). $\varepsilon$ is an error term. We estimate parameters of Eq. (1) by assuming that errors are clustered by individuals. Using this basic equation, we run regressions for our full model, including variables for all channels of trust together as well as for each channel individually.

\section{Full model}

$X_{j}=[$ bank, ins, fin_adv,con_pro,ac_ex,fam, med,fair, eval,famil,

div, esg,cus, onl,f2f,comp, int,cust_ori,edu, iss, sel,fin_gen]

Recommending institution model

$X_{j}=[$ bank, ins, fin_adv, con_pro, sci,fam, med $]$

Product-related factors model

$X_{j}=[$ fair, eval,famil, div, esg,cus $]$

Recommendation process model

$X_{j}=[o n l, f 2 f$, comp, int, cust_ori,$e d u]$

Regulation model

$X_{j}=[$ iss, sel $]$

We present estimates of the full model in the following section; results from partial models are available on request.

\section{Empirical results}

\section{Data description}

Our sample includes German-speaking undergraduate students and young professionals from all sociodemographic groups with varying types of financial literacy. The survey was promoted via social media channels (primarily Facebook and LinkedIn), and data were collected over two and a half weeks (28.07.2020-14.08.2020). In particular, we used a five-point Likert scale (i.e., "No trust at all," "No trust," "Neutral," "Little trust," and "A lot of trust") to measure the self-assessed level of trust in a pension product for each category displayed in Fig. 1. The form of the question follows Sapienza and Zingales (2012). For example, to measure self-evaluated trust in a pension product recommended by a bank advisor, we asked each survey participant:

On a scale from one ("I do not trust it at all") to five ("I trust this product a lot"), how much trust do you have in a financial product that is recommended to you by... ...an expert from a bank?
Questions regarding the remaining variables are shown in Appendix A. Before the survey, we presented the questionnaire to a trial group which consisted of 13 students at our faculty. We calculated a Cronbach alpha to measure the internal consistency of the various items. We obtained an alpha of 0.91 which provides some support for internal consistency. In our final survey, we also collected data on control variables, such as age or gender. Finally, we collected answers from 124 individuals within the age range of 19 to 36 and a median age of 23 . Accordingly, our sample cannot be characterized as representative for the German population. However, it is still informative for an important customer category in the financial industry that is young customers. We removed all survey participants who took less than $90 \mathrm{~s}$ to answer all questions, as this is the minimum time required to answer based on several test runs. Finally, we check our data for individuals who gave the same answer to all questions. However, this was not the case for any of our participants. Following the adjustments made to our dataset, 117 participants remain in the sample. Summary statistics show that men were slightly overrepresented in our sample, accounting for around $60 \%$ of the participants. Moreover, about $80 \%$ of the sample population report that they have at least some or a lot of experience with financial products. The self-reported measures of generalized trust (i.e., trust in other people) and optimism are also slightly skewed toward the upper end of the scale. More precisely, $73 \%$ of the participants in our sample report that they trust other people somewhat or very much. Regarding our measure of optimism, more than $76 \%$ belong to one of the highest two categories (Table 1).

\section{Full model results}

When analyzing the impact of the four different channels for trust in pension products, we provide estimates of the "full model." We use ordered logit and probit models and summarize results in Table 2 (coefficient estimates and the marginal effects (ME) for the lowest ("No trust at all") and highest ("A lot of trust") category of trust). For simplicity, we always state the coefficient of our ordered logit regression first and the coefficient of the probit model second.

\section{Recommending institutions}

Starting by looking at the impact of different recommending institutions on the level of trust in a pension product (see Panel A), the coefficients for having a bank as the recommending party of -0.80 and -0.42 , which are significant at the 1 and $5 \%$ levels, suggest that having this party as the recommender of a financial product significantly reduces the self-evaluated level of trust. Coefficients of -1.24 and 
Table 1 Control variablessummary statistics

\begin{tabular}{ll}
\hline Average age & 23.6 \\
Age range & $19-36$ \\
Women (in \% of total sample) & 39.3 \\
Men (in \% of total sample) & 60.7 \\
Individuals w/ a university degree (in \% of total sample) & 56.4 \\
Individuals w/ at least moderate experience w/ financial products (in \% of total sample) $)^{\mathrm{a}}$ & 79.5 \\
Individuals w/ at least moderate optimism (in \% of total sample) $^{\mathrm{a}}$ & 76.1 \\
Individuals w/ at least a moderate level of generalized trust (in \% of total sample) $^{\mathrm{a}}$ & 73.5 \\
\hline
\end{tabular}

${ }^{a}$ Includes all individuals who assessed this category with a value of more than 3
-0.69 , significant at the highest level, suggest that this effect is similar when the recommending party is an insurance company. The negative impact of having either one of these two financial institutions as the recommending party is also underlined when looking at the marginal effects. In line with our coefficients, there is a modest increase in distrust of between 2 and $5 \%$ for a financial product to be ranked in the lowest trust category and a decrease of between 12 and $18 \%$ to be ranked in the highest category if the recommending party is a bank or an insurance company. While financial advisors, consumer protection agencies, and financial media channels also appear to have a negative impact on the level of trust expressed toward a pension product, the impact is not significant. In contrast, family and friends as well as academic financial experts contribute positively toward the level of trust in a pension product. Inserting the variable for academic financial experts into our full model estimation equation yields highly significant coefficients of 1.15 or 0.70 . This finding is also confirmed by the resulting marginal effects which suggest a decrease in the probability of being ranked in the lowest category of about $1 \%$ and an increase in the probability of being ranked in the highest category of trust of between 23 and $26 \%$ if the recommending party is a family member, a friend, or an academic financial expert. Financial institution should consider these results when developing a marketing strategy for selling pension products. The inclusion of independent experts (such as academics) or a personalized approach by presenting a stylized family member or friend might be a fruitful avenue to follow.

\section{Product characteristics}

Turning to the product characteristics (see Panel B) that were included in the full estimation model, coefficients of 0.55 and 0.39 - significant at the 10 and $5 \%$ levels for distributive fairness-indicate that this factor positively contributes toward establishing trust in a financial product. As before, the resulting marginal effects are in line with the coefficients, which suggests a decrease in the probability of being ranked in lower categories of trust and an increase in probability of being ranked in higher categories. In line with the existing literature, our variable for positive consensus information is positive regardless of the underlying model but lacks statistical significance. Interestingly, familiarity does not seem to have the expected effect within our sample, since we receive negative coefficients for both types of regressions. However, this effect does not appear to be statistically significant. Moreover, our variable assessing the impact of diversification of financial products on trust yields coefficients of 1.11 and 0.65 that are significant at the highest level. As expected, the marginal effects indicate a significant reduction in the probability of being ranked in the lowest category of trust and an increase of between 24 and $25 \%$ to be ranked in the highest category of trust. Therefore, this factor appears to have a similar impact to that of having a family member, friends, or an academic financial expert as the recommending party. The inclusion of the last product-related factor, ESG focus, results in the expected positive sign, but lacks statistical significance. Finally, the coefficients for the factor "customization" are significant at the $1 \%$ level and vary between 0.51 and 0.78 , contributing positively to the highest level of trust and marginally negatively to the lowest level of trust. In sum, the second channel, i.e., product characteristics through which trust can be delivered, is clearly dominated by rational factors, such as diversification and customization effects.

\section{Recommendation process}

Moreover, the inclusion of factors involved in the recommendation process (see Panel C) yields the expected results for most of the variables. Starting with the impact of online interactions on the level of trust in a financial product, our ordered regressions result in coefficients of 1.85 and -1.06 -both significant at the $1 \%$ level for our sample, suggesting that products that are recommended online have a significantly lower chance of being trusted. This becomes even more apparent when considering the 
Table 2 Full model regression results

\begin{tabular}{|c|c|c|c|c|c|c|}
\hline Dependent variable & Full model & Full model & ME (Logit) & ME (Probit) & ME (Logit) & ME (Probit) \\
\hline Trust & (Logit) & (Probit) & ("No trust at all") & & ("A lot of trust") & \\
\hline \multicolumn{7}{|c|}{ Panel A: Recommending institution } \\
\hline Bank & $\begin{array}{l}-0.800 * * * \\
(0.006)\end{array}$ & $\begin{array}{l}-0.415^{* *} \\
(0.014)\end{array}$ & $\begin{array}{l}0.021 * \\
(0.054)\end{array}$ & $\begin{array}{l}0.022^{*} \\
(0.088)\end{array}$ & $\begin{array}{l}-0.127 * * * \\
(0.001)\end{array}$ & $\begin{array}{l}-0.119 * * * \\
(0.003)\end{array}$ \\
\hline Insurance company & $\begin{array}{l}-1.235^{* * *} \\
(0.000)\end{array}$ & $\begin{array}{l}-0.694^{* * *} \\
(0.000)\end{array}$ & $\begin{array}{l}0.041 * * \\
(0.012)\end{array}$ & $\begin{array}{l}0.048^{* *} \\
(0.016)\end{array}$ & $\begin{array}{l}-0.174 * * * \\
(0.000)\end{array}$ & $\begin{array}{l}-0.178^{* * *} \\
(0.000)\end{array}$ \\
\hline Financial advisor & $\begin{array}{l}-0.302 \\
(0.306)\end{array}$ & $\begin{array}{l}-0.170 \\
(0.314)\end{array}$ & $\begin{array}{l}0.006 \\
(0.371)\end{array}$ & $\begin{array}{l}0.007 \\
(0.394)\end{array}$ & $\begin{array}{l}-0.054 \\
(0.270)\end{array}$ & $\begin{array}{l}-0.053 \\
(0.282)\end{array}$ \\
\hline Cons. protec. agency & $\begin{array}{l}-0.251 \\
(0.395)\end{array}$ & $\begin{array}{l}-0.113 \\
(0.504)\end{array}$ & $\begin{array}{l}0.005 \\
(0.447)\end{array}$ & $\begin{array}{l}0.004 \\
(0.550)\end{array}$ & $\begin{array}{l}-0.046 \\
(0.366)\end{array}$ & $\begin{array}{l}-0.036 \\
(0.482)\end{array}$ \\
\hline Academic fin. expert & $\begin{array}{l}1.146^{* * *} \\
(0.000)\end{array}$ & $\begin{array}{l}0.700^{* * *} \\
(0.000)\end{array}$ & $\begin{array}{l}-0.013 * * * \\
(0.000)\end{array}$ & $\begin{array}{l}-0.013^{* * *} \\
(0.000)\end{array}$ & $\begin{array}{l}0.262 * * * \\
(0.000)\end{array}$ & $\begin{array}{l}0.261^{* * *} \\
(0.000)\end{array}$ \\
\hline Family/friends & $\begin{array}{l}1.016 * * * \\
(0.001)\end{array}$ & $\begin{array}{l}0.632 * * * \\
(0.000)\end{array}$ & $\begin{array}{l}-0.012 * * * \\
(0.000)\end{array}$ & $\begin{array}{l}-0.012^{* * * *} \\
(0.000)\end{array}$ & $\begin{array}{l}0.230 * * * \\
(0.002)\end{array}$ & $\begin{array}{l}0.234 * * * \\
(0.001)\end{array}$ \\
\hline Financial media & $\begin{array}{l}-0.162 \\
(0.578)\end{array}$ & $\begin{array}{l}-0.101 \\
(0.550)\end{array}$ & $\begin{array}{l}0.003 \\
(0.605)\end{array}$ & $\begin{array}{l}0.004 \\
(0.589)\end{array}$ & $\begin{array}{l}-0.030 \\
(0.564)\end{array}$ & $\begin{array}{l}-0.033 \\
(0.530)\end{array}$ \\
\hline \multicolumn{7}{|c|}{ Panel B: Product characteristics } \\
\hline Distributive fairness & $\begin{array}{l}0.554 * \\
(0.059)\end{array}$ & $\begin{array}{l}0.386^{* *} \\
(0.023)\end{array}$ & $\begin{array}{l}-0.008^{* *} \\
(0.019)\end{array}$ & $\begin{array}{l}-0.009 * * * \\
(0.001)\end{array}$ & $\begin{array}{l}0.119^{*} \\
(0.082)\end{array}$ & $\begin{array}{l}0.138^{* *} \\
(0.035)\end{array}$ \\
\hline Peer group evaluation & $\begin{array}{l}0.457 \\
(0.120)\end{array}$ & $\begin{array}{l}0.268 \\
(0.115)\end{array}$ & $\begin{array}{l}-0.007^{*} \\
(0.062)\end{array}$ & $\begin{array}{l}-0.007 * * \\
(0.040)\end{array}$ & $\begin{array}{l}0.096 \\
(0.149)\end{array}$ & $\begin{array}{l}0.093 \\
(0.138)\end{array}$ \\
\hline Familiarity & $\begin{array}{l}-0.190 \\
(0.514)\end{array}$ & $\begin{array}{l}-0.103 \\
(0.540)\end{array}$ & $\begin{array}{l}0.004 \\
(0.549)\end{array}$ & $\begin{array}{l}0.004 \\
(0.580)\end{array}$ & $\begin{array}{l}-0.035 \\
(0.495)\end{array}$ & $\begin{array}{l}-0.033 \\
(0.520)\end{array}$ \\
\hline Diversification & $\begin{array}{l}1.113^{* * * *} \\
(0.000)\end{array}$ & $\begin{array}{l}0.648^{* * *} \\
(0.000)\end{array}$ & $\begin{array}{l}-0.013^{* * *} \\
(0.000)\end{array}$ & $\begin{array}{l}-0.012 * * * \\
(0.000)\end{array}$ & $\begin{array}{l}0.254 * * * \\
(0.001)\end{array}$ & $\begin{array}{l}0.240 * * * \\
(0.000)\end{array}$ \\
\hline ESG context & $\begin{array}{l}0.183 \\
(0.530)\end{array}$ & $\begin{array}{l}0.132 \\
(0.436)\end{array}$ & $\begin{array}{l}-0.003 \\
(0.497)\end{array}$ & $\begin{array}{l}-0.004 \\
(0.372)\end{array}$ & $\begin{array}{l}0.037 \\
(0.545)\end{array}$ & $\begin{array}{l}0.044 \\
(0.457)\end{array}$ \\
\hline Customization & $\begin{array}{l}0.780^{* * * *} \\
(0.008)\end{array}$ & $\begin{array}{l}0.510^{* * * *} \\
(0.003)\end{array}$ & $\begin{array}{l}-0.010^{* * *} \\
(0.000)\end{array}$ & $\begin{array}{l}-0.011^{* * *} \\
(0.000)\end{array}$ & $\begin{array}{l}0.172 * * \\
(0.015)\end{array}$ & $\begin{array}{l}0.186 * * * \\
(0.006)\end{array}$ \\
\hline \multicolumn{7}{|c|}{ Panel C: Recommendation process } \\
\hline Online interaction & $\begin{array}{l}-1.847 * * * \\
(0.000)\end{array}$ & $\begin{array}{l}-1.058^{* * *} \\
(0.000)\end{array}$ & $\begin{array}{l}0.083^{* * * *} \\
(0.002)\end{array}$ & $\begin{array}{l}0.102 * * * \\
(0.001)\end{array}$ & $\begin{array}{l}-0.220 * * * \\
(0.000)\end{array}$ & $\begin{array}{l}-0.231^{* * *} \\
(0.000)\end{array}$ \\
\hline Face-to-face interaction & $\begin{array}{l}0.012 \\
(0.968)\end{array}$ & $\begin{array}{l}0.062 \\
(0.714)\end{array}$ & $\begin{array}{l}-0.000 \\
(0.968)\end{array}$ & $\begin{array}{l}-0.002 \\
(0.696)\end{array}$ & $\begin{array}{l}0.002 \\
(0.968)\end{array}$ & $\begin{array}{l}0.020 \\
(0.726)\end{array}$ \\
\hline Competence & $\begin{array}{l}2.041 * * * \\
(0.000)\end{array}$ & $\begin{array}{l}1.242 * * * \\
(0.000)\end{array}$ & $\begin{array}{l}-0.018^{* * *} \\
(0.000)\end{array}$ & $\begin{array}{l}-0.015^{* * *} \\
(0.000)\end{array}$ & $\begin{array}{l}0.469 * * * \\
(0.000)\end{array}$ & $\begin{array}{l}0.464 * * * \\
(0.000)\end{array}$ \\
\hline Integrity & $\begin{array}{l}1.270^{* * * *} \\
(0.000)\end{array}$ & $\begin{array}{l}0.781 * * * \\
(0.000)\end{array}$ & $\begin{array}{l}-0.014^{* * *} \\
(0.000)\end{array}$ & $\begin{array}{l}-0.013^{* * *} \\
(0.000)\end{array}$ & $\begin{array}{l}0.293 * * * \\
(0.000)\end{array}$ & $\begin{array}{l}0.293 * * * \\
(0.000)\end{array}$ \\
\hline Educational components & $\begin{array}{l}1.216^{* * * *} \\
(0.000)\end{array}$ & $\begin{array}{l}0.744^{* * * *} \\
(0.000)\end{array}$ & $\begin{array}{l}-0.014^{* * *} \\
(0.000)\end{array}$ & $\begin{array}{l}-0.013^{* * * *} \\
(0.000)\end{array}$ & $\begin{array}{l}0.279 * * * \\
(0.000)\end{array}$ & $\begin{array}{l}0.279 * * * \\
(0.000)\end{array}$ \\
\hline Customer orientation & $\begin{array}{l}1.124 * * * \\
(0.000)\end{array}$ & $\begin{array}{l}0.709 * * * \\
(0.000)\end{array}$ & $\begin{array}{l}-0.013^{* * *} \\
(0.000)\end{array}$ & $\begin{array}{l}-0.013^{* * *} \\
(0.000)\end{array}$ & $\begin{array}{l}0.257 * * * \\
(0.000)\end{array}$ & $\begin{array}{l}0.264 * * * \\
(0.000)\end{array}$ \\
\hline \multicolumn{7}{|l|}{ Panel D: Regulation } \\
\hline Seller & $\begin{array}{l}0.569^{* *} \\
(0.018)\end{array}$ & $\begin{array}{l}0.340^{* *} \\
(0.014)\end{array}$ & $\begin{array}{l}-0.008 * * * \\
(0.004)\end{array}$ & $\begin{array}{l}-0.008^{* * * *} \\
(0.001)\end{array}$ & $\begin{array}{l}0.122 * * \\
(0.030)\end{array}$ & $\begin{array}{l}0.121 * * \\
(0.020)\end{array}$ \\
\hline Issuer & $\begin{array}{l}0.220 \\
(0.360)\end{array}$ & $\begin{array}{l}0.141 \\
(0.306)\end{array}$ & $\begin{array}{l}-0.004 \\
(0.315)\end{array}$ & $\begin{array}{l}-0.004 \\
(0.239)\end{array}$ & $\begin{array}{l}0.044 \\
(0.380)\end{array}$ & $\begin{array}{l}0.048 \\
(0.322)\end{array}$ \\
\hline Control variables & Yes & Yes & Yes & Yes & Yes & Yes \\
\hline Pseudo $R$-squared & 0.094 & 0.097 & - & - & - & - \\
\hline Observations & 2574 & 2574 & 2574 & 2574 & 2574 & 2574 \\
\hline
\end{tabular}

$p$ values in parentheses. Significance level is denoted by $* * *(1 \%), * *(5 \%)$, and $*(10 \%)$. Control variables include age, gender, education, financial literacy, optimism, generalized trust, and narrow-scope trust 
resulting coefficients for face-to-face interactions, which are slightly positive, but insignificant. Additionally, the marginal effects for our variable for online interaction suggest an increase of between 8 and $10 \%$ in the probability of being ranked in the lowest and a decrease of between 22 and $23 \%$ of being ranked in the highest category of trust. These observations are surprising, since our sample primarily includes young adults aged between 18 and 36 . This age group is often characterized as being digitally native, but our results suggest that digitization of this age-group may be less related to trust in financial products. Furthermore, the impact of the three main drivers of interpersonal trust based on the existing literature-namely competence, integrity, and customer orientation-shows positive and significant contributions toward building trust in financial products, all estimated effects being significant at the $1 \%$ level. While recommending parties that are perceived as competent increase the probability of ranking a financial product in the highest category of trust by around $46 \%$, the effect for parties that are perceived as having a high level of integrity is $29 \%$ and the effect for customer orientation is $26 \%$. Finally, congruent with previous research, the impact of the inclusion of educational components in the recommendation process results in coefficients of 1.22 and 0.74 that are significant at the highest level, suggesting a positive contribution toward trust in financial products. Once again, the marginal effects confirm this result, suggesting a $28 \%$ increase in the likelihood of being ranked in the highest trust category.

\section{Regulation}

The last segment of the full estimation model includes variables regarding the impact of tighter regulation on different actors in the financial system. First, our variable measuring the impact of more regulation for sellers of financial products shows that individuals in our sample would have more trust in financial products if there were more regulation for those actors. This is indicated by coefficients of 0.57 and 0.34 , significant at the $5 \%$ level. This is also underlined when looking at the marginal effects for this variable, which suggest that individuals in our sample would be around $12 \%$ more likely to trust financial products if sellers were more heavily regulated. These observations are compatible with the view that the survey participants understand that sellers of financial products may face a conflict of interest (i.e., sellers of financial products earn more if they sell products with high margins, which, however, are bad for customers). More regulation for issuers of financial products, on the other hand, does not appear to positively contribute toward building trust, as suggested by insignificant coefficients which are close to zero.

\section{Trust and financial literacy}

We additionally run our ordinal regressions by splitting the dataset into high (i.e., answered that they had at least some experience) and low (i.e., answered neutrally or below) financially literate individuals (see Table 3 ). The motivation for this split is that financial literacy seems to be an important factor of trust relationships. For example, in a sample of Dutch consumers, van der Cruijsen et al. (2021) find that primarily financial literate people tend to have a high level of trust in financial institutions. Our results for the recommendation process suggest a different picture when we look at the recommending institution (Panel A). Compared with the full sample (displayed Column (i)), the main positive trust factors in the highly financially literate group (Column (ii)) are primarily academic financial experts and family/friends. Negative trust factors are primarily observed in the low-level financially literate group (Column (iii)) which include banks, insurance companies, consumer protection agencies, and financial media. Thereby, an insurance company also receives distrust from the highly financially literate and less financially literate group. Similarly, highly financially literate individuals tend to perceive product characteristics in general (Panel B) as delivering a higher level of trust than low-level financially literate individuals do. Thereby, diversification characteristics and customization are perceived to be particularly trustworthy by highly financially literate people, while diversification and familiarity characteristics deliver mainly distrust to low-level financially literate people. This indicates that the impact of diversification only helps to build trust for those individuals with an advanced understanding of financial products. In the third channel-characteristics of the recommendation process (Panel C) — competence, integrity, educational components, and customer orientation lose their significance for the low-level financial literacy sample. The last channelregulation (Panel D) - is perceived equally among high and low financial literate people.

In sum, the sample split reveals one major result: Financially literate people tend to drive the perception of positive trust in the second channel (product characteristics) and the third channel (process characteristics), while financially illiterate individuals mainly perceive distrust in these two channels. Thus, an important determinant of trust seems to be the level of financial literacy, and the results of this analysis suggest that improving an individual's financial education may be a promising part of increasing trust in pension products.

\section{Limitations}

Like most empirical analyses, our research design has some potential limitations. First, the correlation analysis in the last section does not address the issue of causation. That 
Table 3 Logit models—role of financial literacy

\begin{tabular}{|c|c|c|c|}
\hline Dependent variable: trust & $\begin{array}{l}\text { Full sample } \\
\text { (i) }\end{array}$ & $\begin{array}{l}\text { High fin. Lit } \\
\text { (ii) }\end{array}$ & $\begin{array}{l}\text { Low fin. lit } \\
\text { (iii) }\end{array}$ \\
\hline \multicolumn{4}{|c|}{ Panel A: Recommending institution } \\
\hline Bank & $\begin{array}{l}-0.800^{* * *} \\
(0.006)\end{array}$ & $\begin{array}{l}-0.408 \\
(0.219)\end{array}$ & $\begin{array}{l}-2.108^{* * * *} \\
(0.002)\end{array}$ \\
\hline Insurance company & $\begin{array}{l}-1.235^{* * *} \\
(0.000)\end{array}$ & $\begin{array}{l}-0.928^{* * * *} \\
(0.005)\end{array}$ & $\begin{array}{l}-2.274 * * * \\
(0.001)\end{array}$ \\
\hline Financial advisor & $\begin{array}{l}-0.302 \\
(0.306)\end{array}$ & $\begin{array}{l}-0.018 \\
(0.957)\end{array}$ & $\begin{array}{l}-1.110 \\
(0.104)\end{array}$ \\
\hline Cons. protec. agency & $\begin{array}{l}-0.251 \\
(0.395)\end{array}$ & $\begin{array}{l}0.201 \\
(0.547)\end{array}$ & $\begin{array}{l}-1.837 * * * \\
(0.007)\end{array}$ \\
\hline Academic fin. expert & $\begin{array}{l}1.146^{* * * *} \\
(0.000)\end{array}$ & $\begin{array}{l}1.494 * * * \\
(0.000)\end{array}$ & $\begin{array}{l}0.108 \\
(0.872)\end{array}$ \\
\hline Family/friends & $\begin{array}{l}1.016^{* * *} \\
(0.001)\end{array}$ & $\begin{array}{l}1.342 * * * \\
(0.000)\end{array}$ & $\begin{array}{l}0.070 \\
(0.918)\end{array}$ \\
\hline Financial media & $\begin{array}{l}-0.162 \\
(0.578)\end{array}$ & $\begin{array}{l}0.208 \\
(0.526)\end{array}$ & $\begin{array}{l}-1.396 * * \\
(0.037)\end{array}$ \\
\hline \multicolumn{4}{|c|}{ Panel B: Product characteristics } \\
\hline Distributive fairness & $\begin{array}{l}0.554^{*} \\
(0.059)\end{array}$ & $\begin{array}{l}0.990 * * * \\
(0.003)\end{array}$ & $\begin{array}{l}-0.768 \\
(0.251)\end{array}$ \\
\hline Peer group evaluation & $\begin{array}{l}0.457 \\
(0.120)\end{array}$ & $\begin{array}{l}0.837 \text { ** } \\
(0.012)\end{array}$ & $\begin{array}{l}-0.697 \\
(0.300)\end{array}$ \\
\hline Familiarity & $\begin{array}{l}-0.190 \\
(0.514)\end{array}$ & $\begin{array}{l}0.123 \\
(0.709)\end{array}$ & $\begin{array}{l}-1.171 * \\
(0.086)\end{array}$ \\
\hline Diversification & $\begin{array}{l}1.113^{* * * *} \\
(0.000)\end{array}$ & $\begin{array}{l}1.832 * * * \\
(0.000)\end{array}$ & $\begin{array}{l}-1.138^{*} \\
(0.085)\end{array}$ \\
\hline ESG context & $\begin{array}{l}0.183 \\
(0.530)\end{array}$ & $\begin{array}{l}0.532 \\
(0.107)\end{array}$ & $\begin{array}{l}-0.941 \\
(0.160)\end{array}$ \\
\hline Customization & $\begin{array}{l}0.780 \text { *** } \\
(0.008)\end{array}$ & $\begin{array}{l}1.149^{* * * *} \\
(0.001)\end{array}$ & $\begin{array}{l}-0.245 \\
(0.709)\end{array}$ \\
\hline \multicolumn{4}{|c|}{ Panel C: Recommendation process } \\
\hline Online interaction & $\begin{array}{l}-1.847 \text { *** } \\
(0.000)\end{array}$ & $\begin{array}{l}-1.468^{* * * *} \\
(0.000)\end{array}$ & $\begin{array}{l}-3.270 * * * \\
(0.000)\end{array}$ \\
\hline Face-to-face interaction & $\begin{array}{l}0.012 \\
(0.968)\end{array}$ & $\begin{array}{l}0.331 \\
(0.314)\end{array}$ & $\begin{array}{l}-0.912 \\
(0.163)\end{array}$ \\
\hline Ability & $\begin{array}{l}2.041^{* * * *} \\
(0.000)\end{array}$ & $\begin{array}{l}2.503 \text { *** } \\
(0.000)\end{array}$ & $\begin{array}{l}0.774 \\
(0.258)\end{array}$ \\
\hline Integrity & $\begin{array}{l}1.270 * * * \\
(0.000)\end{array}$ & $\begin{array}{l}1.547 * * * \\
(0.000)\end{array}$ & $\begin{array}{l}0.630 \\
(0.360)\end{array}$ \\
\hline Educational components & $\begin{array}{l}1.216^{* * *} \\
(0.000)\end{array}$ & $\begin{array}{l}1.652^{* * *} \\
(0.000)\end{array}$ & $\begin{array}{l}-0.049 \\
(0.942)\end{array}$ \\
\hline Customer orientation & $\begin{array}{l}1.124^{* * *} \\
(0.000)\end{array}$ & $\begin{array}{l}1.404 * * * \\
(0.000)\end{array}$ & $\begin{array}{l}0.463 \\
(0.502)\end{array}$ \\
\hline \multicolumn{4}{|l|}{ Panel D: Regulation } \\
\hline Seller & $\begin{array}{l}0.569^{* *} \\
(0.018)\end{array}$ & $\begin{array}{l}0.716^{* * * *} \\
(0.008)\end{array}$ & $\begin{array}{l}0.108 \\
(0.837)\end{array}$ \\
\hline Issuer & $\begin{array}{l}0.220 \\
(0.360)\end{array}$ & $\begin{array}{l}0.333 \\
(0.217)\end{array}$ & $\begin{array}{l}-0.174 \\
(0.732)\end{array}$ \\
\hline Control variables & Yes & Yes & Yes \\
\hline Pseudo $R$-squared & 0.094 & 0.106 & 0.102 \\
\hline Observations & 2574 & 2046 & 528 \\
\hline
\end{tabular}

$p$ values in parentheses. Significance level is denoted by $* * *(1 \%), * *$ $(5 \%)$, and $*(10 \%)$. Control variables include age, gender, education, financial literacy, optimism, generalized trust, and narrow-scope trust is, the one-time survey approach does not allow analyzing the causal effects of various channels of trust. For example, to give regression parameters a causal interpretation survey participants should be treated with different recommendation parties and trust should be measured before and after the treatment. Second, considering the size and structure of our sample (i.e., most research participants have a high level of financial literacy and are young), one must be careful when drawing inferences for the total population. However, since young people are a valuable customer group the results are informative for financial institutions targeting this group. Furthermore, a potential threat to the validity of our estimations is inherent in the questions used in our survey, which may not precisely capture desired effects or which may pick up underlying or related effects. Another weakness of our choice of study design is response bias, meaning that participants inaccurately or falsely answer our questions. However, Chang and Krosnick (2010) suggest that conducting surveys online leads to less survey satisfaction as well as less social desirability response bias. However, results may be helpful for financial institutions when they consider their recommendation process of retirement products.

\section{Conclusion}

In this paper, we have investigated trust in pension products. Our analysis has revealed that trust is a multi-dimensional process where many factors leave their mark on consumer trust. Four channels representing how trust can be transferred to the consumer of retirement products have been identified. First, our results show that trust in pension products is significantly influenced by the recommending institution. However, institutions such as banks and insurance companies, which have struggled to regain trust after the financial crisis of 2008/2009, have a negative effect on trust when they act as a recommending party for a retirement product. On the other hand, parties who are not directly involved in the sales process of financial products and who are usually perceived as having the best interest of other people at heart (i.e., academic financial experts and family/ friends) have a positive influence on trust in financial products. For sellers of financial products, this implies that they could try to use academic expertise in their recommendation process or try to promote referrals from friends and family as part of their sales strategy.

The second channel which supports trust in financial products is that of product-related factors. Congruent with the existing literature, distributive fairness and customization positively contribute toward trust in a financial product based on the results from our sample. Hence, as shown by Loch et al. (2012), sellers of financial products can substantially benefit from competing on fairness rather than 
on price. Furthermore, tailoring financial products to the individual financial needs of clients can additionally help to increase the trust that clients place in the products offered by financial institutions. Also, beneficial product characteristics, such as providing risk diversification, contribute positively toward building trust.

Turning to the third category of variables included in our estimation model-factors involved in the recommendation process-our findings are largely in line with previous research on trust in other contexts. While online interactions appear to have a significantly negative effect on trust in the recommended product, the three most dominant drivers of interpersonal trust comprising ability, integrity, and customer orientation also play a large role in the context of retirement products. Finally, our findings suggest that more regulation for sellers of financial products would contribute to higher levels of trust among our participants, while stronger regulation for issuers would have no effect. However, regulation seems to be the weakest channel for providing trust to consumers.

Our sensitivity analysis further reveals that the level of financial literacy seems to be an important factor in trust relationships. The answers of the survey participants suggest that primarily high financial literate people perceive trust in the pension domain. Therefore, it might make sense for sellers of retirement products to assess the financial literacy of buyers prior to recommending products to them. Then, low-level financially literate buyers would first receive some background information about product characteristics (i.e., a financial education), before a pension product is recommended to them. Also, educational tools should be implemented in the recommendation process for financially illiterate customers before advice about a particular pension product is offered. Therefore, the inclusion of educational components in the recommendation process may help to build trust in a product. However, improving financial literacy can also be addressed in the school educational system as suggested by Lusardi et al. (2010). That is, the financial illiteracy of the young can be reduced before they make important financial decisions such as saving for retirement in later years. Finally, it should be noted that our sample is restricted to young people (i.e., students and young professionals). Thus, further research could explore whether our results also apply to more representative samples.

\section{Appendix}

\section{Survey questions}

"Financial product" is a broad term that is used in a variety of contexts. For the scope of this survey, please consider a "financial product" to be the following: a product (often in the form of a contract) sold to consumers as part of their retirement planning or for the accumulation of wealth by financial institutions such as banks, insurance companies, brokerage firms, and consumer finance companies. When answering the questions, please consider the following products: life insurance, Riester-Rente, ETFs, and mutual funds.

\section{Specific questions}

\section{Recommending party}

On a scale from one ("I do not trust it at all") to five ("I trust this product a lot"), how much trust do you have in a financial product that is recommended to you by...
a. ...an expert from a bank?
b. ....an expert from an insurance company?
c. ....an expert from a financial advisory firm?
d. ....an expert from a consumer protection agency?
e. ....an academic financial expert?
f. ....an expert among your family or friends?
g. ....an expert via financial media (e.g., financial mag- azines, blogs, podcasts, etc.)?

\section{Product-related factors}

On a scale from one ("I do not trust it at all") to five ("I trust this product a lot"), how much trust do you have in a financial product...

a. ... that you perceive to be fair in terms of pricing?

b. ...that has exclusively positive reviews?

c. ...sold by a financial services institution whose products you are already using (e.g., a checking account)?

d. ...that consists of multiple securities? (e.g., ETFs)

e. ...that exclusively invests in securities that meet high environmental and social standards (i.e., ESG standards)?

f. ...that is customized to your financial situation?

\section{Recommendation process}

On a scale from one ("I do not trust it at all") to five ("I trust this product a lot"), how much trust do you have in a financial product that is recommended to you ...

a. ...online?

b. ...in a face-to-face interaction?

c. ...by someone who you perceive to be competent and to have a high level of financial expertise?

d. ...by someone who you perceive to be honest and reliable and who you expect to keep their word?

e. ...by someone who you believe is acting in your best interest? 
f. ...by someone who makes sure that you fully understand how the financial product works (e.g., using informational videos, brochures, etc.)?

\section{Regulation}

On a scale from one ("Strongly disagree") to five ("Strongly agree"), how much do you agree with the following statement: "I would have more trust in financial products, if...."

a. ...issuers of financial products were more heavily regulated."

b. ...sellers of financial products were more heavily regulated."

c. ...the financial sector in general were more heavily regulated."

\section{General questions}

- How old are you?

- What is your gender?

- What is the highest academic degree that you have obtained?

- Experience

o How experienced are you with financial products on a scale from one ("no experience") to five ("very experienced")?

- Optimism

o How much do you agree with the following statement: "In general, more good things than bad things happen to me" on a scale from one ("I do not agree at all") to five ("I totally agree")?

- General level of trust

o In general, how much do you think other people can be trusted on a scale from one ("not at all") to five ("very much")?

- Narrow-scope trust

o How much do you think the financial services sector can be trusted on a scale from one ("not at all") to five ("very much")?

Funding Open Access funding enabled and organized by Projekt DEAL.

\section{Declarations}

Conflict of interest On behalf of all authors, the corresponding author states that there is no conflict of interest.

Open Access This article is licensed under a Creative Commons Attribution 4.0 International License, which permits use, sharing, adaptation, distribution and reproduction in any medium or format, as long as you give appropriate credit to the original author(s) and the source, provide a link to the Creative Commons licence, and indicate if changes were made. The images or other third party material in this article are included in the article's Creative Commons licence, unless indicated otherwise in a credit line to the material. If material is not included in the article's Creative Commons licence and your intended use is not permitted by statutory regulation or exceeds the permitted use, you will need to obtain permission directly from the copyright holder. To view a copy of this licence, visit http://creativecommons.org/licenses/by/4.0/.

\section{References}

Abrams, L.C., R. Cross, E. Lesser, and D.Z. Levin. 2003. Nurturing interpersonal trust in knowledge-sharing networks. Academy of Management Perspectives 17 (4): 64-77.

Adaval, R. 2003. How good gets better and bad gets worse: Understanding the impact of affect on evaluations of known brands. Journal of Consumer Research 30 (3): 352-367.

Aggarwal, P., and R.P. Larrick. 2012. When consumers care about being treated fairly: The interaction of relationship norms and fairness norms. Journal of Consumer Psychology 22 (1): 114-127.

Agnew, J.R., L.R. Szykman, S.P. Utkus, and J.A. Young. 2012. Trust, plan knowledge and 401(k) savings behavior. Journal of Pension Economics and Finance 11: 1-20.

Aghion, P., Y. Algan, P. Cahuc, and A. Shleifer. 2010. Regulation and distrust. The Quarterly Journal of Economics 125 (3): 1015-1049.

Alesina, A., and E. La Ferrara. 2002. Who trusts others? Journal of Public Economics 85 (2): 207-234.

Ba, S., and P.A. Pavlou. 2002. Evidence of the effect of trust building technology in electronic markets: Price premiums and buyer behavior. MIS Quarterly 26: 243-268.

Benedicktus, R.L., M.K. Brady, P.R. Darke, and C.M. Voorhees. 2010. Conveying trustworthiness to online consumers: Reactions to consensus, physical store presence, brand familiarity, and generalized suspicion. Journal of Retailing 86 (4): 322-335.

Benedict, S.K., B.S.K. Koh, O.S. Mitchell, and J.H. Fong. 2021. Trust and retirement preparedness: Evidence from Singapore. Journal of the Economics of Ageing 18: 1-10.

Brady, M.K., J.J. Cronin Jr., G.L. Fox, and M.L. Roehm. 2008. Strategies to offset performance failures: The role of brand equity. Journal of Retailing 84 (2): 151-164.

Brodie, H., and K. Harnack. 2019. The trust mandate: The behavioural science behind how asset managers really win and keep clients. Petersfield: Harriman House.

Buchan, N.R., R.T. Croson, and S. Solnick. 2008. Trust and gender: An examination of behavior and beliefs in the Investment Game. Journal of Economic Behavior and Organization 68 (3-4): 466-476.

Chaiken, S. 1989. Heuristic and systematic information processing within and beyond the persuasion context. In Unintended Thought, 212-52. 
Chang, L., and J.A. Krosnick. 2010. Comparing oral interviewing with self-administered computerized Questionnaires: An experiment. Public Opinion Quarterly 74 (1): 154-167.

Cialdini, R.B. 1987. Influence, vol. 3. Port Harcourt: A. Michel.

Colombo, R.J. 2010. The role of trust in financial regulation. Villanova Law Review 55: 577.

Colquitt, J.A., B.A. Scott, and J.A. LePine. 2007. Trust, trustworthiness, and trust propensity: A meta-analytic test of their unique relationships with risk taking and job performance. Journal of Applied Psychology 92 (4): 909.

Coulter, K.S., and R.A. Coulter. 2003. The effects of industry knowledge on the development of trust in service relationships. International Journal of Research in Marketing 20 (1): 31-43.

Crosby, L.A., K.R. Evans, and D. Cowles. 1990. Relationship quality in services selling: An interpersonal influence perspective. Journal of Marketing 54 (3): 68-81.

Croson, R., and U. Gneezy. 2009. Gender differences in preferences. Journal of Economic Literature 47 (2): 448-474.

Deetlefs, A.M.J., H. Bateman, L.I. Dobrescu, B.R. Newell, A. Ortmann, and S. Thorp. 2019. Engagement with retirement savings: It is a matter of trust. Journal of Consumer Affairs 53 (3): 917-945.

Devlin, J.F., C.T. Ennew, H.S. Sekhon, and S.K. Roy. 2015. Trust in financial services: Retrospect and prospect. Journal of Financial Services Marketing 20 (4): 234-245.

Doney, P.M., and J.P. Cannon. 1997. An examination of the nature of trust in buyer-seller relationships. Journal of Marketing 61 (2): $35-51$

Dreber, A., and M. Johannesson. 2008. Gender differences in deception. Economics Letters 99 (1): 197-199.

Ennew, C., H. Kharouf, and H. Sekhon. 2011. Trust in UK financial services: A longitudinal analysis. Journal of Financial Services Marketing 16 (1): 65-75.

Ennew, C., and H. Sekhon. 2007. Measuring trust in financial services: The trust index. Consumer Policy Review 17 (2): 62.

Fungácová, Z., I. Hasan, and L. Weill. 2019. Trust in banks. Journal of Economic Behavior and Organization 157: 452-476.

Georgarakos, D., and G. Pasini. 2011. Trust, sociability, and stock market participation. Review of Finance 15 (4): 693-725.

Gill, H., K. Boies, J.E. Finegan, and J. McNally. 2005. Antecedents of trust: Establishing a boundary condition for the relation between propensity to trust and intention to trust. Journal of Business and Psychology 19 (3): 287-302.

Guiso, L., P. Sapienza, and L. Zingales. 2004. The role of social capital in financial development. American Economic Review 94 (3): 526-556.

Guiso, L., P. Sapienza, and L. Zingales. 2008. Trusting the stock market. The Journal of Finance 63 (6): 2557-2600.

Gulati, R. 1995. Does familiarity breed trust? The implications of repeated ties for contractual choice in alliances. Academy of Management Journal 38 (1): 85-112.

Hong, H., J.D. Kubik, and J.C. Stein. 2004. Social interaction and stock-market participation. The Journal of Finance 59 (1): 137-163.

Keller, K.L. 1993. Conceptualizing, measuring, and managing customer-based brand equity. Journal of Marketing 57 (1): 1-22.

Knack, S., and P. Keefer. 1997. Does social capital have an economic payoff? A cross-country investigation. The Quarterly Journal of Economics 112 (4): 1251-1288.

Larzelere, R.E., and T.L. Huston. 1980. The dyadic trust scale: Toward understanding interpersonal trust in close relationships. Journal of Marriage and the Family 42: 595-604.

Lind, E.A. 2001. Fairness heuristic theory: Justice judgments as pivotal cognitions in organizational relations. In Advances in organization justice, ed. J. Greenberg and R. Cropanzano, 56-88. Stanford University Press.
Loch, C., F. Sting, A. Huchzermeier, and C. Decker. 2012. Finding the profit in fairness. Harvard Business Review 90 (10): 111-115.

Luhmann, N. 1979. 1979 Trust and power. Chichester: Wiley.

Lusardi, A., O.S. Mitchell, and V. Curto. 2010. Financial literacy among the young. Journal of Consumer Affairs 44 (2): 358-380.

Maheswaran, D., D.M. Mackie, and S. Chaiken. 1992. Brand name as a heuristic cue: The effects of task importance and expectancy confirmation on consumer judgments. Journal of Consumer Psychology 1 (4): 317-336.

Mayer, R.C., J.H. Davis, and F.D. Schoorman. 1995. An integrative model of organizational trust. Academy of Management Review 20 (3): 709-734.

McFall, L. 1987. Integrity. Ethics 98 (1): 5-20.

Moin, S., J.F. Devlin, and S. McKechnie. 2015. Trust in financial services: Impact of institutional trust and dispositional trust on trusting belief. Journal of Financial Services Marketing 20 (2): 91-106.

Moorman, C., R. Deshpande, and G. Zaltman. 1993. Factors affecting trust in market research relationships. Journal of Marketing 57 (1): $81-101$

Morgan, R.M., and S.D. Hunt. 1994. The commitment-trust theory of relationship marketing. Journal of Marketing 58 (3): 20-38.

Nilsson, M., and J. Mattes. 2013. The spatiality of trust: Antecedents of trust and the role of face-to-face contacts.

Osili, U.O., and A.L. Paulson. 2008. Institutions and financial development: Evidence from international migrants in the United States. The Review of Economics and Statistics 90 (3): 498-517.

Ostrom, A., and D. Lacobucci. 1995. Consumer trade-offs and the evaluation of services. Journal of Marketing 59 (1): 17-28.

Peel, M.J., M.M. Goode, and L.A. Moutinho. 1998. Estimating consumer satisfaction: OLS versus ordered probability models. International Journal of Commerce and Management 8 (2): 75-93.

Pinotti, P. 2012. Trust, regulation and market failures. Review of Economics and Statistics 94 (3): 650-658.

Puri, M., and D.T. Robinson. 2007. Optimism and economic choice. Journal of Financial Economics 86 (1): 71-99.

Ricci, O., and M. Caratelli. 2017. Financial literacy, trust and retirement planning. Journal of Pension Economics \& Finance 16 (1): 43-64.

Rousseau, D.M., S.B. Sitkin, R.S. Burt, and C. Camerer. 1998. Not so different after all: A cross-discipline view of trust. Academy of Management Review 23 (3): 393-404.

Roy, S.K., J.F. Devlin, and H. Sekhon. 2015. The impact of fairness on trustworthiness and trust in banking. Journal of Marketing Management 31 (9-10): 996-1017.

Sapienza, P., and L. Zingales. 2012. A trust crisis. International Review of Finance 12 (2): 123-131.

Sitkin, S.B., and N.L. Roth. 1993. Explaining the limited effectiveness of legalistic "remedies" for trust/distrust. Organization Science 4 (3): 367-392.

Sheppard, B.H., and D.M. Sherman. 1998. The grammars of trust: A model and general implications. Academy of Management Review 23 (3): 422-437.

Solomon, L. 1960. The influence of some types of power relationships and game strategies upon the development of interpersonal trust. The Journal of Abnormal and Social Psychology 61 (2): 223-230.

Stewart, K.J. 2003. Trust transfer on the world wide web. Organization Science 14 (1): 5-17.

Storper, M., and A.J. Venables. 2004. Buzz: Face-to-face contact and the urban economy. Journal of Economic Geography 4 (4): $351-370$. 
Strickland, L.H. 1958. Surveillance and trust. Journal of Personality 26: 200-215.

Uzzi, B. 1996. The sources and consequences of embeddedness for the economic performance of organizations: The network effect. American Sociological Review 61: 674-698.

van der Cruijsen, C., J. de Haan, and R. Roerink. 2021. Financial knowledge and trust in financial institutions. Journal of Consumer Affairs 55 (2): 680-714.

van Rooij, M., A. Lusardi, and R. Alessie. 2007. Financial literacy and stock market participation. Journal of Financial Economics 101 (2): 449-472.

Wei, C., and L. Zhang. 2014. Trust and certification in financial markets: Evidence from reactions to earnings news. SSRN 2469034.

Williamson, O. E. 1985. The economic institutions of capitalism: Firms, markets, relational contracting. New York.

Xie, Y., and S. Peng. 2009. How to repair customer trust after negative publicity: The roles of competence, integrity, benevolence, and forgiveness. Psychology and Marketing 26 (7): 572-589.

Zeffane, R., and S.J.B. Melhem. 2017. Trust, job satisfaction, perceived organizational performance and turnover intention. Employee Relations: THe International Journal 39 (7): 1148-1167.

Publisher's Note Springer Nature remains neutral with regard to jurisdictional claims in published maps and institutional affiliations.

Philip Maximilian Linhart is a student at Frankfurt School of Finance and Management specializing in Financial Institutions and Capital Markets. In addition, he has been working in the financial industry for several years.

Olaf Stotz holds a chair in Asset Management and Pension Economics. Previously to his academic career, he has worked in the financial industry for several years. He also serves on various supervisory boards of financial institutions. 